\title{
PENDIDIKAN PESANTREN BERBASIS MULTIPLE INTELLEGENCES (KECERDASAN MAJEMUK)
}

Received: 18-02-2020 Revised: 06-05-2020 Accepted: 12-06-2020

\section{Muhammad Anas Ma `arif ${ }^{1}$, Muhammad Husnur Rofiq ${ }^{2}$, Nur Silva Nabila ${ }^{3}$}

Fakultas Tarbiyah Institut Pesantren KH Abdul Chalim Mojokerto Indonesia ${ }^{1,2}$, Universitas Islam Negeri Sunan Ampel Surabaya Indonesia ${ }^{1}$

Anasdt16@gmail.com, umasoviq@gmail.com, nursilvanabila24@gmail.com

\section{Keywords: Islamic Bording School, Education, Multiple Inteligences}

\begin{abstract}
This article explains the importance of educational innovation for developing students' intelligence. Multiple Intelligences MI (multiple intelligences) is a small part of innovation in the education sector as an answer to the division of intelligence which is only motivated by intellectual, spiritual and emotional. Multiple Intelligences divides intelligence in children into eight so that with this division the interests and talents of students as well as their potential are explored in a directed and channeled manner. MI is widely applied in school institutions, which are formal in nature, but this nation forgets the education that produces many ulama', namely pesantren. thus the pesantren should be a serious concern for the development of students / students. And with this educational innovation, hopefully it will be a little solution for education in this country.
\end{abstract}

Abstrak
Artikel ini menjelaskan pentingnya inovasi pendidikan untuk
mengembangkan kecerdasan peserta didik. Multiple
Intelligences MI (kecerdasan majemuk) adalah sebagian kecil
inovasi di bagian pendidikan sebagai jawaban atas pembagian
kecerdasan yang hanya terpacu pada intellectual, spiritual dan
emosiaonal. Multiple Intelligences membagi kecerdasan pada
anak menjadi delapan sehingga dengan pembagian tersebut
minat dan bakat peserta didik sekaligus potensinya tergali
secara terarah dan tersalurkan. MI banyak di terapkan di
lembaga-lembaga sekolah, yang bersifat formal akan tetapi
bangsa ini lupa dengan pendidikan yang mencetak banyak
ulama` yaitu pesantren. dengan demikian seharusnya
pesantren menjadi perhatian serius untuk pengembangan
santri/peserta didik. Dan dengan adanya inovasi pendidikan
ini semoga menjadi sedikit solusi untuk pendidikan di negeri
ini.




\section{PENDAHULUAN}

Manusia adalah mahluk yang mendapatkan kesempurnaan di bandingkan dengan mahluk lain yaitu diberi akal yang aman dengan akal bisa membedakan antara perkara yang baik dan perkara yang buruk1. Dan dengan akal tersebut seharusnya di manfaatkan sebaik-baiknya untuk masalah akhirat (keagamaan seperti ibadah) atau masalah keduniaan (sosial, dan muamalah)².

Akal adalah ciptaan Allah yang indah dan penuh dengan rahasia-rahasia yang mempunyai potensi untuk membentuk pola pikir yang terencana, tersruktur dan terarah ${ }^{3}$. Dan potensi-potensi manusia diwujudkan dalam bentuk yang berbeda-beda. Bentuk intrepertasi dari potensi tersebut dapat berupa kemampuan berbahasa, berlogika, olah tubuh, bermain music, berkerja sama dengan orang lain, memahami kemampuan diri hingga kemampuan berekplorasi dengan alam ${ }^{4}$.

Bentuk tersebut yang kemudian disebut dengan Multiple Intellegences (MI) yang di kenalkan oleh Howard Gradner $1983^{5}$ dan teori tersebut di bagi menjadi sembilan kecerdasan manusia. Beragam kecerdasan yang dimilik oleh manusia seharusnya bisa dikembangkan dalam ranah pendidikan yang selama ini terkesan kaku dalam memberikan materi pelajaran dan metode pembelajaran.

Terlebih lagi jika teori tersebut di terapkan di lingkungan pesantren yang selama ini bersifat kaku dan kurang inovasi di dalam kurikulum. Meskipun pesantren berusaha mengembangkan kurikulum yang lebih efisien dan dinamis, dan orientasi kurikulum tersebut tersebut yang bisa memberikan implikasi bahwa

1 Ah Zakki Fuad, 'Rekonstruksi Tujuan Pendidikan Islam Berbasis Taksonomi Transenden', ISLAMICA: Jurnal Studi Keislaman 9, no. 2 (15 March 2016): 424-46, https://doi.org/10.15642/islamica.2015.9.2.424-446.

2 Abuddin Nata, 'Revitalisasi Pendidikan Karakter Untuk Mencetak Generasi Unggul', Didaktika Religia 1, no. 1 (2013).

3 Wahyuddin Wahyuddin, 'Fungsi Pendidikan Islam Dalam Hidup Dan Kehidupan Manusia (Manusia Yang Memiliki Fitrah/Potensi Dan Sebagai Makhluk Yang Harus Dididik/Mendidik)', Inspiratif Pendidikan 5, no. 2 (2016): 399-415.

4 Titin Nurhidayati, 'Inovasi Pembelajaran Pai Berbasis Multiple Intelligences', Jurnal Pendidikan Agama Islam (Journal of Islamic Education Studies) 3, no. 1 (7 February 2016): 24, https://doi.org/10.15642/jpai.2015.3.1.23-56; - Siskandar, 'Pengembangan Multiple Intelligences Melalui Kegiatan Non-Intrakurikuler dalam Rangka Meningkatkan Mutu Proses dan Hasil Pembelajaran', Jurnal Ekonomi $\mathcal{E}$ Pendidikan 5, no. 2 (2008): 125, http://journal.uny.ac.id/index.php/jep/article/view/593.

${ }^{5}$ Howard Gardner, ‘Reflections on Multiple Intelligences: Myths and Messages', Phi Delta Kappan 77, no. 3 (1995): 200, http:/ / search.proquest.com/openview/4bbb940abb34c54f7705833b2c879283/1?pq-origsite=gscholar.

Vol.1, No.1, June 2020, 
bahwa pesantren sudah berusaha memenuhi tuntunan dan kebutuhan kehidupan modern ${ }^{6}$.

Pendidikan pesantren merupakan segala aktivitas pendidikan yang dilaksanakan dipesantren, baik pendidikan jalur sekolah maupun jalur di luar sekolah7. Pendidikan ini diarahkan untuk pada upaya untuk memberikan bekal pengetahuan, (knowledge) sikap, (attitude) keterampilan (skill) pada semua santri ${ }^{8}$. Pesantren merupakan pendidikan yang bersifat klasik dan bertujuan untuk mencetak generasi yang Islami ${ }^{9}$. Dan dilihat dari sejarah yang telah ada di Indonesia bahwa pesantren banyak mengeluarkan Ulama' yang berbakat tidak hanya di bidang agama saja melainkan juga di bidang yang lainya. Seperti, KH. Abdurrahman Wahid lulusan pesantren yang bisa menjadi kepala Negara ${ }^{10}$.

Untuk mengoptimalkan pendidikan yang ada dipesantren, ternyata selama ini pesantren juga telah mengadopsi teori MI yang sudah di terapkan selama awal mula berdirinya pesantren, hanya saja tidak terstruktur seperti Gardner yang menjelaskan kecerdasan anak secara psikologi yang terbagi Sembilan. Meskipun menerapkan beberapa teori dalam MI pesantren ternyata masih kurang inovasi dalam melaksanakan hal tersebut.

Seperti halnya dalam penerimaan santri (input) ${ }^{11}$ banyak di setiap pesantren menerima semua pendaftaran santri tidak ada seleksi seperti sekolah yang menklasifikasikan hanya pada tingkat kognitif saja, ini jelas bertentangan dengan tujuan pendidikan nasional atau disebut juga dengan pendidikan kapitalis. Oleh

${ }^{6}$ Muhammad Anas Ma`arif and Eka Deni Sulistyanik, 'PENGEMBANGAN POTENSI PESERTA DIDIK DALAM PEMBELAJARAN PENDIDIKAN AGAMA ISLAM BERBASIS KECERDASAN MAJEMUK (MULTIPLE INTELLIGENCE)', Al-Tarbawi Al-Haditsah: Jurnal Pendidikan Islam 4, no. 2 (31 December 2019), https:/ / doi.org/10.24235/tarbawi.v4i2.5216.

7 Zamakhsyari Dhofier, Tradisi pesantren: studi pandangan hidup kyai dan visinya mengenai masa depan Indonesia, Cet. 8 rev (Jakarta: LP3ES, 2011).

8 H. M. Djumransjah, 'Pendidikan Pesantren Dan Kemandirian Santri', Jurnal Ilmu Pendidikan 8, no. 2 (5 February 2016): 140.

9 Madjid Nurcholis, Bilik-Bilik Pesantren Sebuah Potret Perjalanan, 6th ed. (Jakarta: Paramadina Grup, 2016).

10 Wawan Arwani, 'Kiai Pesantren Dan Kontribusinya Dalam Mengembangkan Pluralitas Keberagamaan Dan Toleransi Di Kabupaten Cirebon', Holistik 15, no. 1 (5 April 2016), https://doi.org/10.24235/holistik.v15i1.434.

11 Peserta didik (masukan)atau individu yang meiliki berbagai potensi dasar (fitrah) yang memerlukan pengembangan melalui proses pendidikan. Ahmad Jamin, 'Pendidikan Islam Sebagai Sebuah Sistem (Transformasi Input Menuju Output Yang Berkarakter)', ISLAMIKA 15, no. 2 (2016): 182, http://ejournal.iainkerinci.ac.id/index.php/islamika/article/view/47. 
Muhammad Anas Ma`arif, Muhammad Husnur Rofiq, Nur Silva Nabila

sebab itu, penelitian ini akan mencoba menjawab bagaimanakah mengintegrasikan pendidikan yang ada di pesantren dengan kecerdasan majemuk?

\section{PEMBAHASAN}

\section{Karakteristik Pendidikan pesantren}

Pesantren merupakan pendidikan yang tertua di Indonesia abad ke $13^{12}$ yang bisa bertahan sampai sekarang. Dunia pesantren juga sangat beragam. Masingmasing pesantren memiliki keunikan-keunikan sehingga sangat sulit untuk dibuat satu merumuskan teori tentang pesantren. pesantren adalah lembaga tradisonal Islam yang mempelajari, memahami, mendalami, menghayati, dan mengamalkan ajaran Islam dengan menekankan pentinya moral keagamaan sebagai pedoman moral perilaku sehari-hari'13.

Pesantren adalah suatu lembaga pendidikan islam yang tumbuh serta diakui masyarakat sekitar dengan system asrama. Para santri menerima pendidikan agama melalui system pengajian atau madrasah yang sepenuhnya berada dibawah kadulatan kepemimpinan seorang atau beberapa Kyai ${ }^{14}$. Kemudian lembaga research Islam mendefinisikan pondok pesantren adalah suatu tempat yang tersedia untuk para santri dalam menerima pelajaran-pelajaran agama Islam sekaligus tempat berkumpul dan tempat tinggal para santri tersebut ${ }^{15}$.

Mujammil Qomar menyatakan bahwa pondok pesantren memiliki persepsi yang plural. Pondok pesantren dapat dipandang sebagai lembaga ritual, lembaga pembinaan moral, lembaga dakwah, dan yang paling popular adalah sebagai institusi pendidikan Islam yang mengalami proses romantika kehidupan dalam menghadapi berbagai tantangan internal maupun eksternal. ${ }^{16}$

Zamakhsyari Dhofier menyebutkan ada lima unsur dasar sebuah pondok pesantren yaitu, pondok (asrama) masjid, kyai, santri, pengajaran kitab-kitab klasik Islam ${ }^{17}$. Kemudian Mujammil Qomar menyebutkan sebuah pondok pesantren

12 Ismail Suardi Wekke, 'Pesantren Dan Pengembangan Kurikulum Kewirausahaan: Kajian Pesantren Roudahtul Khuffadz Sorong Papua Barat', Inferensi 6, no. 2 (2012): 209, http://inferensi.iainsalatiga.ac.id/index.php/inferensi/article/viewFile/148/109.

13 Mastuhu, Dinamika sistem pendidikan pesantren: suatu kajian tentang unsur dan nilai sistem pendidikan pesantren, 2nd ed. (Jakarta: INIS, 1994), 55.

${ }^{14}$ M Arifin, Kapita Selekta Pendidikan Islam dan Umum, (Jakarta: Bumi Aksara, 1991) hal. 200

15 Lembaga Reseach Islam (Pondok Pesantren Luhur) Sejarah dan Dakwah Islamiyah Sunan Giri (Malang: Panitia Penelitian dan Pemugaran Sunan Giri Gresik, 1975) hal. 45

16 Mujamil Qomar, Pesantren: dari transformasi metodologi menuju demokratisasi institusi (Ciracas, Jakarta: Erlangga, 2005), 15.

17 Zamakhsyari Dhofier, Tradisi Pesantren hal, 79

Vol.1, No.1, June 2020, 
memiliki empat unsur dasar yaitu pondok (asrama), masjid, santri, dan kyai. Jika keempat unsure dasar tersebut telah dimiliki oleh satu lembaga pengajian tertentu maka status lembaga tersebut telah berubah menjadi pondok pesantren. ${ }^{18}$

Karakter pesantren memang sangat berbeda-beda. banyak berbagai pandangan tentang pengelompokan jenis-jenis atau kategorisasi pondok pesantren Zamakhsyari Dhofier memandang pondok pesantren menjadi dua kategori, yaitu pondok pesantren salafi dan pondok pesantren khalafi. Pondok pesantren salafi tetap mengajarkan kitab-kitab Islam klasik sebagai inti pendidikanya. Penetapan system madrasah untuk memudahkan system madrasah untuk memudahkan system sorogan yang dipakai dalam lembaga-lembaga pengajian bentuk lama, tanpa mengenalkan pengajaran pengetahuan umum. Sedangkan pondok pesantren khalafi telah memasukan pelajaran-pelajaran umumdalam madrasah-madrasah yang dikembangkan atau membuka tipe-tipe sekolah umum di dalam lingkungan pondok pesantren ${ }^{19}$.

Martin van Bruinessen mengelompokan pondok pesantren berdasarkan muatan kurikulumnya menjadi tiga kategori, yaitu pondok pesantren paling sederhana, pondok pesantren sedang, dan pondok pesantren maju. Pondok pesantren sederhana adalah pondok pesantren yang mengajarkan cara membaca huruf arab dan menghafal Al-Quran. Pondok pesantren sedang adalah pondok pesantren yang mengajarkan berbagai kitab fiqih, ilmu akidah, tata bahasa Arab, terkadang amaln sufi. Sedangkan pondok pesantren maju adalah pondok pesantren yang mengajarkan kitab-kitab fiqih, aqidah, dan tasawuf yang lebih mendalam dan beberapa mata pelajaran tradisional ${ }^{20}$.

Sedangkan M Arifin mengklasifikasikan pondok pesantren berdasarkan kurikulumnya kedalam tiga kategori, yaitu pondok pesantren modern, tahassus (secara kusus mendalami ilmu-ilmu tertentu, sebagai contoh pendalam ilmu fiqih (ibadah), hadist, Al-Quran dan pondok pesantren campuran²1.

18 Qomar, Pesantren, 18.

19 Zamakhsyari Dhofier, Tradisi Pesantren hal, 41

20 Van Bruinessen Martin, Kutab Kuning Pesantren dan Tarekat, 1st ed. (Yogyakarta: Gading Publising, 2012), 20.

21 M Arifin, Kapita Selekta Pendidikan,..251-252 
Ahmad Qadri Abdillah Azizy membagi pondok pesantren atas dasar kelembagaanya yang dikaitakan dengan system pengajarannya menjadi lima kategori: (1) pondok pesantren yang menyelenggarakan pendidikan formal dengan menerpkan kurikulum nasional, baik yang hanya memilki sekolah keagamaan maupun yang juga memiliki sekolah umum. (2) Pondok pesantren yang menyelenggarakan pendidikan keagamaan dalam bentuk madrasah dan mengajarkan ilmu-ilmu umum meski tidak menerapkan kurikulum nasional. (3) Pondok pesantren yang hanya mengajarkan ilmu-ilmu agama dalam bentuk madrasah diniyah (4) pondok pesantren yang hanya sekedar menjadi tempat pengajian atau biasa disebut dengan majlis ta lim (5) Pondok pesantren untuk asrama anak-anak belajar sekolah umum dan mahasiswa ${ }^{22}$.

Adapula yang mengaktegorisasikan pondok pesantren dari system pendidikan yang dikembangkan.pondok pesantren dengan kategorisasi seperti ini menjadi tiga jenis: Kelompok pertama, memiliki santri yang belajar dan tinggal bersama kyai, kurikulum tergantung kyai, dan pengajaran secara individual. Kelompok kedua, meiliki madrasah, kurikulum tertenntu, santri bertempat tinggal di asrama untuk mempelajari ilmu agama dan umum. Kelompok ketiga, hanya berupa asrama, santri belajar disekolah, madrasah, bahkan perguruan tinggi agama atau umum di luar, kyai sebagai pengawas Pembina mental23.

Pola pembinaan pesantren dibagi menjadi dua bagian, bagian yang pertama adalah menggunakan metode-metode tradisonal (Sorogan dan Bandongan), sedangkan yang kedua adalah menggunakan metode-metode kombinatif.

\section{Metode tradisonal}

Metode tradisional merupakan metode pembelajaran yang dilakukan oleh pesantren tradisional yang terbagi menjadi dua bagian sebagai berikut:

1) Bandongan, atau wetonan adalah metode paling utama di lingkungan pesantren. Zamakhsyari Dhofier menjelaskan bahwa metode wethonan, menerangkan dan mengulas buku-buku Islam dalam bahasa Arab sedang sekolmpok santri mendengarkannya. Mereka memperhatikan bukunya

22 Ahmad Qodry Abdillah Azizy, Pengantar Memberdayakan Pondok Pesantren dan Madrasah (Yogyakarta: Pustaka Pelajar, 2002) hal. viii

${ }^{23}$ Suparlan Suryopratondo, Kapita Selekta Pondok Pesantren, (Jakarta: Paryu Barkah, 2005) hal. 84

Vol.1, No.1, June 2020, 
sendiri dan membuat catatan-catatan (baik arti maupun keterangan) dengan kata-kata atau buah pikiran yang sulit.

2) Metode sorogan merupakan suatu metode yang ditempuh dengan cara guru menyampaikan pelajaran kepada santri secara individual, biasanya disamping dipesantren juga dilangsungkan dilanggar, masjid atau terkadang di rumah-rumah. Penyampaian pelajaran kepada santri-santri secara bergilir ini biasanya dipraktekan kepada santri yang jumelahnya sedikit.

Dipesantren sasaran metode ini adalah kelompok santri yang tingkat rendah yaitu mereka yang baru menguasai pembacaan Al-Quran. System sorogan dalam pengajian ini merupakan bagian yang sangat sulit dari keseluruhan system pendidikan pesantren, sebab system sorogan menuntut kesabaran, kerajinan, ketaatan dan disiplin pribadi guru pembimbing dan murid 24 .

\section{Metode kombinatif}

Mengenai metode pesantren pada mulanya menggunakan metode-metode tradisional yaitu metode, sorogan, wetonan, muhawaroh, nadzkaih dan metode majelis ta'lim. Metode bandongan ini adalah hasil adaptasi dengan metode pengajaran agama di Timur Tengah terutama Makkah dan Al azhar Mesir. Kemudian pesantren perlu mengambil alih metodeik pendidikan nasional. Para Kyai pesantren yang tergabung dalam Rabithat Al-Ma`ahid dalam muktamar ke I pada 1959 memutuskan metode Tanya jawab, diskusi, proyek, dialog, karyawisata, hafalah/verbalisme, sosiodrama, widyawisata, problem solving, pemberian situasi, pembiasaan/habituasi, percontohan tingkah laku, reinforcement, stimulus respon, dan system modul meskipin agak sulit. Tetapi metode-metode tersebut belum diterapkan secara optimal ${ }^{25}$.

${ }^{24}$ Zamakhsyari Dhofier, Tradisi Pesantren hal, 55

25 Muhammad Anas Ma'arif, 'Hukuman (Punishment) Dalam Perspektif Pendidikan Di Pesantren', Ta'allum: Jurnal Pendidikan Islam 5, no. 1 (1 June 2017): 1-20, https://doi.org/10.21274/taalum.2017.5.1.1-20; Muhammad Anas Maarif et al., 'Character Education Through Dhikr Tariqa Qadiriyya Naqhsabandiyya Al-Usmaniyya Indonesia', Hampstead Psychological Associates 24, no. 07 (2020): 9; Ma'arif, 'Hukuman (Punishment) Dalam Perspektif Pendidikan Di Pesantren'. 


\section{Musyawarah}

Dalam kelas musyawarah, system pengajaranya sangat berbeda dengan system sorogan dan bandongan. Para siswa harus mempelajari sendiri kitabkitabnya yang ditunjuk dan dirujuk, kyai memimpin kelas musyawarah seperti dalam suatu seminar dan lebih banyak dalam bentuk tanya-jawab biasanya hampir seluruhnya dalam bentuk bahasa Arab, dan merupakan latihan bagi siswa untuk menguji kemampuan dan keterampilannya dalam menyadap sumber-sumber argumentasi dalam kitab-kitab Islam klasik2627.

\section{Multiple Intellegences (kecerdasan majemuk)}

Multiple Intelligence adalah teori kecerdasan majemuk yang dipaparkan Prof. Howard Gardner. Multiple intelligence atau kecerdasan majemuk pada dasarnya adalah sebuah konsep yang menunjukkan kepada kita bahwa potensi anak-anak kita, khususnya jika dikaitkan dengan kecerdasan,ternyata banyak sekali. Memahami multiple intelligence bukanlah untuk membuat anak-anak kita menjadi hebat. Namun,konsep tersebut, paling tidak dapat membantu kita untuk memahami bahwa anak-anak kita itu menyimpan potensi yang luar biasa.

Pengertian dari kecerdasan menurut Howard Gardner adalah suatu kemampuan untuk memecahkan masalah dan menciptakan produk yang mempunyai nilai budaya atau suatu kumpulan kemampuan atau ketrampilan yang dapat ditumbuhkembangkan ${ }^{28}$. Sedangkan multiple intelegence (kecerdasan majemuk) adalah kecerdasan yang dimiliki oleh tiap individu lebih dari satu macam. Menurut Howard Gardner setiap individu delapan jenis kecerdasan di dalam dirinya,yang disebut kecerdasan majemuk (multiple intelligence) ${ }^{29}$.

Prestasi seseorang ditentukan juga oleh tingkat kecerdasannya (Inteligensi). Walaupun mereka memiliki dorongan yang kuat untuk berprestasi dan orang tuanya memberi kesempatan seluas-luasnya untuk meningkatkan prestasinya, tetapi kecerdasan mereka yang terbatas tidak memungkinkannya untuk mencapai

${ }^{26}$ Muhammad Anas Ma`arif and Ari Kartiko, 'Fenomenologi Hukuman di Pesantren : Analisis Tata Tertib Santri Pondok Pesantren Daruttaqwa Gresik', Nadwa 12, no. 1 (22 June 2018): 181-96, https:// doi.org/10.21580/nw.2018.12.1.1862.

27 Zamakhsyari Dhofier, Tradisi Pesantren hal, 57

${ }_{28}$ Gardner, "Reflections on Multiple Intelligences," 13. 2002), 13.

${ }^{29}$ Howard Gardner, Multiple intelligences: the theory in practice, 30. dr (New York, NY: Basic Books,

Vol.1, No.1, June 2020, 
keunggulan. Tingkat Kecerdasan (Intelegensi) bawaan ditentukan baik oleh bakat bawaan (berdasarkan gen yang diturunkan dari orang tuanya) maupun oleh faktor lingkungan (termasuk semua pengalaman dan pendidikan yang pernah diperoleh seseorang; terutama tahun-tahun pertama dari kehidupan mempunyai dampak kuat terhadap kecerdasan seseorang). Secara umum intelegensi dapat dirumuskan sebagai berikut:

1. Kemampuan untuk berpikir abstrak

2. Untuk menangkap hubungan-hubungan dan untuk belajar

3. Kemampuan untuk menyesuaikan diri terhadap situasi-situasi baru

Konsep multiple intelligence diperkenalkan oleh Prof. Howard Gardner, yaitu seorang psikolog dan profesor utama di Cognition and Education, Harvard Graduate School of Education dan juga profesor di bidang Neurologi, Boston University School of Medicine. Konsep ini memiliki esensi bahwa setiap orang adalah unik, setiap orang perlu menyadari dan mengembangkan ragam kecerdasan manusia dan kombinasi-kombinasinya. Setiap siswa berbeda karena mempunyai kombinasi kecerdasan yang berlainan.

Melalui konsepnya mengenai multiple intelligences atau kecerdasan ganda ini Gardner mengoreksi keterbatasan cara berpikir yang konvensional mengenai kecerdasan dari tunggal menjadi jamak. Kecerdasan tidak terbatas pada kecerdasan intelektual yang diukur dengan menggunakan beberapa tes inteligensi yang sempit saja, atau sekadar melihat prestasi yang ditampilkan seorang peserta didik melalui ulangan maupun ujian di sekolah belaka, tetapi kecerdasan juga menggambarkan kemampuan peserta didik pada bidang seni, spasial, olah-raga, berkomunikasi, dan cinta akan lingkungan.

\section{Kecerdasan matematika-logika (Logical mathematical intelligence)}

Kecerdasan matematika-logika menunjukkan kemampuan seseorang dalam berpikir secara induktif dan deduktif, berpikir menurut aturan logika, memahami dan menganalisis pola angka-angka, serta memecahkan masalah dengan menggunakan kemampuan berpikir ${ }^{30}$. Peserta didik dengan kecerdasan

${ }^{30}$ Muslim Afandi, 'Pendidikan islam dan multiple intelligences', Potensia: jurnal kependidikan islam 13, no. 2 (10 December 2014): 143, http://ejournal.uinsuska.ac.id/index.php/potensia/article/view/1044. 
matematika-logika tinggi cenderung menyenangi kegiatan menganalisis dan mempelajari sebab akibat terjadinya sesuatu.

Ia menyenangi berpikir secara konseptual, misalnya menyusun hipotesis dan mengadakan kategorisasi dan klasifikasi terhadap apa yang dihadapinya. Peserta didik semacam ini cenderung menyukai aktivitas berhitung dan memiliki kecepatan tinggi dalam menyelesaikan problem matematika. Apabila kurang memahami, mereka akan cenderung berusaha untuk bertanya dan mencari jawaban atas hal yang kurang dipahaminya tersebut. Peserta didik ini juga sangat menyukai berbagai permainan yang banyak melibatkan kegiatan berpikir aktif, seperti catur dan bermain teka-teki.

\section{Kecerdasan bahasa (verbal linguistic intelligence)}

Kecerdasan bahasa menunjukkan kemampuan seseorang untuk menggunakan bahasa dan kata-kata, baik secara tertulis maupun lisan ${ }^{31}$, dalam berbagai bentuk yang berbeda untuk mengekspresikan gagasan-gagasannya. Peserta didik dengan kecerdasan bahasa yang tinggi umumnya ditandai dengan kesenangannya pada kegiatan yang berkaitan dengan penggunaan suatu bahasa seperti membaca, menulis karangan, membuat puisi, menyusun kata-kata mutiara, dan sebagainya.

Peserta didik seperti ini juga cenderung memiliki daya ingat yang kuat, misalnya terhadap nama-nama orang, istilah-istilah baru, maupun hal-hal yang sifatnya detail. Mereka cenderung lebih mudah belajar dengan cara mendengarkan dan verbalisasi. Dalam hal penguasaan suatu bahasa baru, peserta didik ini umumnya memiliki kemampuan yang lebih tinggi dibandingkan dengan peserta didik lainnya.

\section{Kecerdasan musikal (musical/rhythmic intelligence)}

Kecerdasan musikal menunjukkan kemampuan seseorang untuk peka terhadap suara-suara nonverbal yang berada di sekelilingnya, termasuk dalam hal ini adalah nada dan irama ${ }^{32}$. Peserta didik jenis ini cenderung senang sekali mendengarkan nada dan irama yang indah, entah melalui senandung yang dilagukannya sendiri, mendengarkan tape recorder, radio, pertunjukan orkestra,

${ }^{31}$ Mushollin Mushollin, 'Penerapan Teori Multiple InTeLligences Howard Gardner Dalam Pembelajaran Pendidikan Agama Islam’, Jurnal Tadris Stain Pamekasan 4, no. 2 (2013): 230.

32 Nurhidayati, 'Inovasi Pembelajaran Pai Berbasis Multiple Intelligences', 41-56. 
Tafkir: Interdisciplinary Journal of Islamic Education

Vol.1, No.1, June 2020, , DOI:

Hal: 1-19, E-ISSN-

atau alat musik dimainkannya sendiri. Mereka juga lebih mudah mengingat sesuatu dan mengekspresikan gagasan-gagasan apabila dikaitkan dengan musik.

\section{Kecerdasan visual-spasial (visual spatial intelligence)}

Kecerdasan visual-spasial menunjukkan kemampuan seseorang untuk memahami secara lebih mendalam hubungan antara objek dan ruang. Peserta didik ini memiliki kemampuan, misalnya, untuk menciptakan imajinasi bentuk dalam pikirannya atau kemampuan untuk menciptakan bentuk-bentuk tiga dimensi seperti dijumpai pada orang dewasa yang menjadi pemahat patung atau arsitek suatu bangunan.

Kemampuan membayangkan suatu bentuk nyata dan kemudian memecahkan berbagai masalah sehubungan dengan kemampuan ini adalah hal yang menonjol pada jenis kecerdasan visual-spasial ini. Peserta didik demikian akan unggul, misalnya dalam permainan mencari jejak pada suatu kegiatan di kepramukaan.

\section{Kecerdasan kinestetik (body/kinesthetic intelligence)}

Kecerdasan kinestetik menunjukkan kemampuan seseorang untuk secara aktif menggunakan bagian-bagian atau seluruh tubuhnya untuk berkomunikasi dan memecahkan berbagai masalah. Hal ini dapat dijumpai pada peserta didik yang unggul pada salah satu cabang olahraga, seperti bulu tangkis, sepakbola, tenis, renang, dan sebagainya, atau bisa pula dijumpai pada peserta didik yang pandai menari, terampil bermain akrobat, atau unggul dalam bermain sulap.

\section{Kecerdasan interpersonal (interpersonal intelligence)}

Kecerdasan interpersonal menunjukkan kemampuan seseorang untuk peka terhadap perasaan orang lain. Mereka cenderung untuk memahami dan berinteraksi dengan orang lain sehingga mudah bersosialisasi dengan lingkungan di sekelilingnya ${ }^{33}$. Kecerdasan semacam ini juga sering disebut sebagai kecerdasan sosial, yang selain kemampuan menjalin persahabatan yang akrab dengan teman, juga mencakup kemampuan seperti memimpin,

33 Nurhidayati, 42-56. 
mengorganisir, menangani perselisihan antar teman, memperoleh simpati dari peserta didik yang lain, dan sebagainya.

\section{Kecerdasan intrapersonal (intrapersonal intelligence)}

Kecerdasan intrapersonal menunjukkan kemampuan seseorang untuk peka terhadap perasaan dirinya sendiri. Ia cenderung mampu untuk mengenali berbagai kekuatan maupun kelemahan yang ada pada dirinya sendiri34. Peserta didik semacam ini senang melakukan instropeksi diri, mengoreksi kekurangan maupun kelemahannya, kemudian mencoba untuk memperbaiki diri. Beberapa diantaranya cenderung menyukai kesunyian dan kesendirian, merenung, dan berdialog dengan dirinya sendiri.

\section{Kecerdasan naturalis (naturalistic intelligence)}

Kecerdasan naturalis menunjukkan kemampuan seseorang untuk peka terhadap lingkungan alam, misalnya senang berada di lingkungan alam yang terbuka seperti pantai, gunung, cagar alam, atau hutan. Peserta didik dengan kecerdasan seperti ini cenderung suka mengobservasi lingkungan alam seperti aneka macam bebatuan, jenis-jenis lapisan tanah, aneka macam flora dan fauna, benda-benda angkasa, dan sebagainya.

\section{Kecerdasan spiritual (spiritualist intelligence)}

Kecerdasan spiritual adalah kecerdasan yang menyangkut kemampuan manusia mengenal Tuhannya, meyakini keberadaan dan keEsaan Tuhan, serta melakukan segala apa yang diperintahkan dan menjauhi segala yang dilarangNya. Dalam menjalani kehidupan ia tidak akan putus harapan, karena ada Tuhan tempat bergantung segala sesuatu, dalam keadaan bahagia, ada Tuhan tempat dia melantunkan puja dan puji syukur. Kecerdasan ini akan membentuk jiwa dan pribadi yang berakhlak mulia dan bermanfaat bagi dirinya, keluarga, masayarakat dan negaranya.

\section{Kecerdasan eksistensial (exsistensialist intelligence)}

Kecerdasan eksistensial adalah kemampuan untuk menempatkan diri dalam jagat raya yang luas,jauh tak terhingga dan menghubungkannya dengan kehidupan selanjutnya (kematian). Kecerdasan ini melibatkan kemampuan manusia dalam menjawab berbagai macam persoalan terdalam tentang

${ }^{34}$ Afandi, 'Pendidikan islam dan multiple intelligences', 145. 
eksistensi atau keberadaan manusia. Para ahli filsafat (Filosof) merupakan salah satu bukti kecerdasan ini, diantaranya adalah Plato, Sokrates, Immanuel Kant, Ibnu Sina, Ibnu Rusyd. Mereka berpikir dan memikirkan tentang eksistensi manusia dan alam.

\section{Integrasi Pendidikan Pesantren Berbasis Multiple Intelligence}

Walaupun pesantren bisa dikatakan sebagai tempat pendidikan tradisional, tetapi pesantren tidak pernah menolak peserta didik (santri) untuk menimba ilmu di pesantren tersebut. Ini sangat berjalan dengan apa yang digambarkan oleh Howard gardner bahwa untuk merekrut siswa janganlah di pilih-pilih sebab, tidak ada anak yang tidak pandai (bodoh), akan tetapi belum memiliki pendidik yang tepat.

Pendidikan yang bagus adalah pendidikan yang input-nya (masukan) berupa barang-barang yang ronsokan (dalam hal ini tidak ada seleksi untuk peserta didik), atau merekrut semua peserta didik. Proses yang bagus dan memiliki output (lulusan) yang kompetitif. Yang selama ini kita sadari bahwa praktek pendidikan di Indonesia semakin kapitalis yaitu dalam hal input selalu diseleksi yang bagus-bagus untuk di didik sedangkan yang tidak masuk kualifikasi tidak diperkenankan untuk belajar di tempat tersebut.

Pola umum madrasah/sekolah di Indonesia yang membuka pendaftaran sebanyak-banyaknya, kemudian mengadakan test seleksi. Misalnya, dari 350 pendaftar, yang diterima hanya 100 siswa siswi. Siapakah 100 siswa-siswi tersebut? Pastinya mereka adalah yang menduduki peringkat 1 sampai dengan 100 dari 250 siswa-siswi tersebut. Lalu bagaimana dengan nasib peserta didik 250 yang tidak lolos? Stigma gagal lolos sekolah favorit akan melekat dalam pikiran peserta didik tersebut. ${ }^{35}$

Jika yang diseleksi adalah peserta didik yang bagus (kognitifnya), maka akan dikemanakan untuk peserta didik yang tidak masuk kuaifikasi? Kebanyakan peserta didik akan lari pada lembaga-lembaga yang bisa menerimanya, seperti pesantren atau lembaga-lembaga seperti madrasah ${ }^{36}$. Pesantren sendiri tidak pernah 41.

35 Eni Purwati, 'Pendidikan Islam Berbasis Multiple Inteligences System (mis)', Uin Surabaya, 2011,

36 Eni Purwati et al., Pendidikan Karakter: Menjadi Berkarakter Muslim-Muslimah Indonesia (Surabaya: Kopertais Wilayah IV Surabaya, 2014), http:/ / digilib.uinsby.ac.id/29870/. 
membati peserta didiknya, pesantren dianalogikan seperti rumah sakit, dan santri di ibaratkan sebagai orang yang sakit untuk berobat kerumah sakit. Maka dengan analogi inilah banyak berbagai pesantren menerima santri yang sakit, baik moralnya, atau masalah agama.

Hal ini senada dengan teori Gradner bahwa seorang sejatinya tidak bodoh, hanya saja belum menemukan seorang guru yang tepat untuk mereka. Oleh sebab itu proses perekrutan yang sedemikian sejalan dengan teori kecerdasan majemuk yang nanti akan dijelaskan bagaimana cara proses dalam mendidik santri.

Ketika pesantren banyak yang berpendapat bahwa pendidikan dipesantren terkenal dengan konservatif atau kuno bahkah dikatakan kurang bisa menjadikan peserta didik menjadi pribadi yang di cita-citakan oleh tujuan pendidikan baik secara Islami atau secara konstitusional. Cara pembelajaran juga dikenal sangat tradisonal hanya dengan bandongan, sorogan, atau kombinasi.

Akan tetapi banyak yang melupakan bahwa pesantren mengajari santrinya sesuai dengan tipikal mereka (kecerdasan bawaan), seperti, pembelajaran pencak silat, qiro'ah, bersholawat, pengelolaan kebun, pengelolaan peternakan, pengelolaan administrasi, jual beli, driver, tehnik bangunan dan lain-lain. ${ }^{37}$

Pendidikan bukan hanya mengedepankan kecerdasan kognitif saja akan tetapi juga mengembangkan bakat dan minat peserta didik sehingga benar dalam bersikap dan membentuk karakter yang sesuai dengan nilai-nilai agama dan tujuan pendidikan. Proses pembelajaran di pesantren juga mengembangkan bakat minat peserta didik yang sesua dengan kecerdasan mereka. Misalkan santri setelah belajar di madrasah di ajari juga sesuai bakat kemampuan mereka seperti ada ekstrakulikuler al-banjar (bersolawat), membantu di peternakan, membantu di administrasi. Dan lain sebagainya ${ }^{38}$.

37 Zainal Abidin, 'Implementasi Pendidikan Life Skill Di Pondok Pesantren Darussalam Blokagung Banyuwangi', Jurnal Darussalam: Jurnal Pendidikan, Komunikasi Dan Pemikiran Hukum Islam 6, no. 1 (22 May 2017): http://ejournal.iaida.ac.id/index.php/darussalam/article/view/86; Muhammad Anas Ma'arif and Nur Silva Nabila, 'The Contribution Of Kiai Munawwar Adnan Kholil Gresik On Islamic Education', Tribakti: Jurnal Pemikiran Keislaman 31, no. 2 (20 July 2020): 218-36, https://doi.org/10.33367/tribakti.v31i2.1126.

38 Muhammad Anas Maarif and Muhammad Husnur Rofiq, 'Pola Pengembangan Kurikulum Pendidikan Pesantren Berkarakter : Studi Implementasi Pendidikan Berkarakter di Pondok Pesantren Nurul Ummah Mojokerto' 13 (2018): 16. 
Kelemahan pesantren sendiri dalam menerapakan proses pembelajaranya tidak diarahkan seperti analisis psikologis santri untuk menentukan kecerdasan manjemuk tersebut sesuai dengan kecerdasan santri tersebut. Akan tetapi diberi keleluasaan untuk memilih sendiri. Terkadang juga beberapa santri yang apatis terhadap kecerdasanya sendiri karena beberapa kegiatan tersebut tidak sistematis seperti yang ada pada lembaga Yimmi di Gresik ${ }^{39}$.

Pesantren seharusnya menyusun lesson plan, dengan memperhatikan delapan kecerdasan yang dominan, gaya belajar dan kondisi siswa. Penggunaan strategi pembelajaran di pesantren juga harus lebih variatif sesuai dengan cara kerja otak secara holistic activities dan whole brain dengan variasi metode aktivitas tugas serta sesuai dengan kecerdasan santri ${ }^{40}$.

Karena guru adalah faktor penentu hasil tidaknya pendidikan santri di pesantren, maka seharusnya guru/ pendidik di pesantren memenuhi syarat dan sifat guru sebagai berikut:

1) Guru harus mengetahui karakter murid

2) Guru harus berusaha meningkatkan keahlianya, baik dalam bidang yang diajarkanya maupun dalam cara mengajarkanya

3) Guru harus mengamalkan ilmunya, jangan berbuat berlawanan dengan ilmu yang diajarkanya ${ }^{41}$

Mengenai output santri ini juga harus diperhatikan dengan jelas. Untuk penilaian siswa sebagai pendidik jangan hanya mengacu pada kognitif santri saja akan tetapi harus diperhatikan psikomotornya (produk/karya hasil belajar), dan afektif (sikap/respon santri selama pembelajaran atau prilaku sehari-hari di pesantren.

Pesantren sendiri belum terstruktur seperti tersebut dalam menerapkan hasil penilaian santri. kebanyakan hanya menilai secara kognitif saja. Santri mempunyai kecerdasan dominan yang berbeda-beda sehingga dalam penilaian santri sesuai dengan yang diharapkannya. Meskipun kenyataannya pesantren telah mencetak

39 Anisatun Nur Laili, 'Implementasi pembelajaran Pendidikan Agama Islam berbasis multiple intelligences di SMP Yayasan Islam Malik Ibrahim (YIMI) Gresik "full day school"' (undergraduate, Universitas Islam Negeri Maulana Malik Ibrahim, 2016), http://etheses.uinmalang.ac.id/3943/.

40 Eni Purwanti, Pendidikan Islam Berbasis Multiple Intelligence, ..25

41 Sri Esti Wuryani, Psikologi Pendidikan (Jakarta: Raja Grafindo Persada, 2005), 57. 
banyak ulama` seperi Abdurrahman Wahid (Gusdur) presiden ke 4, KH. Hasyim As`ari, dan lain-lain. Mencetak banyak Intelek seperti KH. Said Agil Sirajl, Mhafud MD, dan lain-lain. Banyak juga beberapa santri sekarang telah bersaing dengan beberapa lembaga sekolah Negeri yang juga lebih unggul seperti di Amanatul Ummah, yaitu santrinya lulusan 2015 keterima di berbagai kampus luar negeri. ${ }^{42}$

Ada moment untuk mengembangkan hal tersebut bagi pesantren karena cara pandang religiusitas. Masyarakat telah, sedang, dan akan terus berubah. Kecenderungan terbaru masyarakat perkotaan sedang bergerak ke arah yang semakin religius. Indikatornya adalah semakin diminati dan semaraknya kajian dan berbagai kegiatan keagamaan. Modernitas membawa implikasi negatif dengan adanya ketidakseimbangan antara kebutuhan rohani dan jasmani. Untuk itu masyarakat tidak ingin hal yang sama akan menimpa anak-anak mereka. Intinya, ada keinginan untuk melahirkan generasi yang lebih agamis atau memiliki nilai-nilai hidup yang baik mendorong orang tua mencarikan sistem pendidikan alternatif. ${ }^{43}$

\section{KESIMPULAN}

Pesantren dalam menerapkan MI (multiple intelligences) kurang menyeluruh dan kurang terstruktur. Input pesantren dalam menerima santri adalah dengan tidak memilih (seleksi secara kognitif) seperti kebanyakan lembaga favorif di Indonesia. Proses pembelajaran di pesantren meskipun terkenal konservatik/ tradisonal telah mengembangkan bakat dan minat peserta didik sesuai minatnya santri akan tetapi bakat santri yang ada pada dirinya kurang tersalurkan karena kurang bimbingan yang secara intensif dan kuranya campur tangan pendidik dib again pengembangan minat. Output pesantren dalam hal menilai masih menggunakan penilaian secara kognitif. Belum kombinasi dengan psikomotor dan afektif siswa. Dan juga belum di atur dalam peraturan pesantren.

42 Majalah Ponpes Amanatul Ummah dan Institu KH Abdul Chalim, Edisi 3 2016, hal. 7-9

43 Umar Sidiq, 'Pengembangan Standarisasi Pondok Pesantren', Nadwa 7, no. 1 (2013): 82, http://journal.walisongo.ac.id/index.php/Nadwa/article/view/544. 
Tafkir: Interdisciplinary Journal of Islamic Education

Vol.1, No.1, June 2020, , DOI:

Hal: 1-19, E-ISSN-

\section{REFERENSI}

Abidin, Zainal. 'Implementasi Pendidikan Life Skill Di Pondok Pesantren Darussalam Blokagung Banyuwangi'. Jurnal Darussalam: Jurnal Pendidikan, Komunikasi Dan Pemikiran Hukum Islam 6, no. 1 (22 May 2017): 162-73. http:/ / ejournal.iaida.ac.id/index.php/darussalam/article/view/86.

Afandi, Muslim. 'Pendidikan islam dan multiple intelligences'. Potensia: jurnal kependidikan islam 13, no. 2 (10 December 2014): 135-48. http:/ / ejournal.uinsuska.ac.id/index.php/potensia/article/view/1044.

Arwani, Wawan. 'Kiai Pesantren Dan Kontribusinya Dalam Mengembangkan Pluralitas Keberagamaan Dan Toleransi Di Kabupaten Cirebon'. Holistik 15, no. 1 (5 April 2016). https:// doi.org/10.24235/holistik.v15i1.434.

Dhofier, Zamakhsyari. Tradisi pesantren: studi pandangan hidup kyai dan visinya mengenai masa depan Indonesia. Cet. 8 rev. Jakarta: LP3ES, 2011.

Djumransjah, H. M. 'Pendidikan Pesantren Dan Kemandirian Santri'. Jurnal Ilmu Pendidikan 8, no. 2 (5 February 2016).

Fuad, Ah Zakki. 'Rekonstruksi Tujuan Pendidikan Islam Berbasis Taksonomi Transenden'. ISLAMICA: Jurnal Studi Keislaman 9, no. 2 (15 March 2016): 42446. https:/ / doi.org/10.15642/islamica.2015.9.2.424-446.

Gardner, Howard. Multiple intelligences: the theory in practice. 30. dr. New York, NY: Basic Books, 2002.

- - - 'Reflections on Multiple Intelligences: Myths and Messages'. Phi Delta Kappan 77, no. 300 (1995): http:/ / search.proquest.com/openview/4bbb940abb34c54f7705833b2c879283 /1?pq-origsite $=$ gscholar.

Jamin, Ahmad. 'Pendidikan Islam Sebagai Sebuah Sistem (Transformasi Input Menuju Output Yang Berkarakter)'. ISLAMIKA 15, no. 2 (2016). http:/ / ejournal.iainkerinci.ac.id/index.php/islamika/article/view/47.

Laili, Anisatun Nur. 'Implementasi pembelajaran Pendidikan Agama Islam berbasis multiple intelligences di SMP Yayasan Islam Malik Ibrahim (YIMI) Gresik "full day school"'. Undergraduate, Universitas Islam Negeri Maulana Malik Ibrahim, 2016. http:/ / etheses.uin-malang.ac.id/3943/. 
Muhammad Anas Ma`arif, Muhammad Husnur Rofiq, Nur Silva Nabila

Ma`arif, Muhammad Anas, and Ari Kartiko. 'Fenomenologi Hukuman di Pesantren: Analisis Tata Tertib Santri Pondok Pesantren Daruttaqwa Gresik'. Nadwa 12, no. 1 (22 June 2018): 181-96. https://doi.org/10.21580/nw.2018.12.1.1862.

Ma`arif, Muhammad Anas, and Eka Deni Sulistyanik. 'PENGEMBANGAN POTENSI PESERTA DIDIK DALAM PEMBELAJARAN PENDIDIKAN AGAMA ISLAM BERBASIS KECERDASAN MAJEMUK (MULTIPLE INTELLIGENCE)'. Al-Tarbawi Al-Haditsah: Jurnal Pendidikan Islam 4, no. 2 (31 December 2019). https:// doi.org/10.24235/tarbawi.v4i2.5216.

Ma'arif, Muhammad Anas. 'Hukuman (Punishment) Dalam Perspektif Pendidikan Di Pesantren'. Ta'allum: Jurnal Pendidikan Islam 5, no. 1 (1 June 2017): 1-20. https:/ / doi.org/10.21274/taalum.2017.5.1.1-20.

Ma'arif, Muhammad Anas, and Nur Silva Nabila. 'The Contribution Of Kiai Munawwar Adnan Kholil Gresik On Islamic Education'. Tribakti: Jurnal Pemikiran Keislaman 31, no. 2 (20 July 2020): 218-36. https://doi.org/10.33367/ tribakti.v31i2.1126.

Maarif, Muhammad Anas, and Muhammad Husnur Rofiq. ‘Pola Pengembangan Kurikulum Pendidikan Pesantren Berkarakter: Studi Implementasi Pendidikan Berkarakter di Pondok Pesantren Nurul Ummah Mojokerto' 13 (2018): 16 .

Maarif, Muhammad Anas, Muhammad Mujtaba Mitra Zuana, Siti Maryam Munjiat, Ibnu Rusydi, Ali Miftakhu Rosyad, and Lu'lu'il Maknuun. 'Character Education Through Dhikr Tariqa Qadiriyya Naqhsabandiyya Al-Usmaniyya Indonesia'. Hampstead Psychological Associates 24, no. 07 (2020): 9.

Martin, Van Bruinessen. Kutab Kuning Pesantren dan Tarekat. 1st ed. Yogyakarta: Gading Publising, 2012.

Mastuhu. Dinamika sistem pendidikan pesantren: suatu kajian tentang unsur dan nilai sistem pendidikan pesantren. 2nd ed. Jakarta: INIS, 1994.

Mushollin, Mushollin. 'Penerapan Teori Multiple InTelligences Howard Gardner Dalam Pembelajaran Pendidikan Agama Islam'. Jurnal Tadris Stain Pamekasan 4, no. 2 (2013): 223-235. 
Nata, Abuddin. 'Revitalisasi Pendidikan Karakter Untuk Mencetak Generasi Unggul'. Didaktika Religia 1, no. 1 (2013).

Nurcholis, Madjid. Bilik-Bilik Pesantren Sebuah Potret Perjalanan. 6th ed. Jakarta: Paramadina Grup, 2016.

Nurhidayati, Titin. 'Inovasi Pembelajaran Pai Berbasis Multiple Intelligences'. Jurnal Pendidikan Agama Islam (Journal of Islamic Education Studies) 3, no. 1 (7 February 2016): 23-56. https:// doi.org/10.15642/jpai.2015.3.1.23-56.

Purwati, Eni. 'Pendidikan Islam Berbasis Multiple Inteligences System (mis)'. Uin Surabaya, 2011, 41.

Purwati, Eni, Zumrotul Mukaffa, Syafi'i Syafi'i, Muhammad Thohir, Evi Fatimatur Rusydiyah, and Muhammad Nuril Huda. Pendidikan Karakter: Menjadi Berkarakter Muslim-Muslimah Indonesia. Surabaya: Kopertais Wilayah IV Surabaya, 2014. http://digilib.uinsby.ac.id/29870/.

Qomar, Mujamil. Pesantren: dari transformasi metodologi menuju demokratisasi institusi. Ciracas, Jakarta: Erlangga, 2005.

Sidiq, Umar. 'Pengembangan Standarisasi Pondok Pesantren'. Nadwa 7, no. 1 (2013): 71-88. http://journal.walisongo.ac.id/index.php/Nadwa/article/view/544. Siskandar, -. ‘Pengembangan Multiple Intelligences Melalui Kegiatan NonIntrakurikuler dalam Rangka Meningkatkan Mutu Proses dan Hasil Pembelajaran'. Jurnal Ekonomi $\mathcal{E}$ Pendidikan 5, no. 2 (2008). http://journal.uny.ac.id/index.php/jep/article/view/593.

Wahyuddin, Wahyuddin. 'Fungsi Pendidikan Islam Dalam Hidup Dan Kehidupan Manusia (Manusia Yang Memiliki Fitrah/Potensi Dan Sebagai Makhluk Yang Harus Dididik/Mendidik)'. Inspiratif Pendidikan 5, no. 2 (2016): 399415.

Wekke, Ismail Suardi. 'Pesantren Dan Pengembangan Kurikulum Kewirausahaan: Kajian Pesantren Roudahtul Khuffadz Sorong Papua Barat'. Inferensi 6, no. 2 (2012): 205-226. http://inferensi.iainsalatiga.ac.id/index.php/inferensi/article/viewFile/14 $8 / 109$.

Wuryani, Sri Esti. Psikologi Pendidikan. Jakarta: Raja Grafindo Persada, 2005. 